\title{
Mirjana llle
}

\section{VLOGA IDENTITETNIH KAPITALOV V RAZVOJU AKTIVNE ODRASLOSTI V GLOBALIZIRANIH DRUŽBAH}

\section{POVZETEK}

$V$ članku razpravljamo o učinkih globalizacije na spremembo življenjskih potekov. Izhajamo iz teze, da individualizacija in destandardizacija življenjskega poteka terja od ljudi večjo pripravljenost za odgovorno načrtovanje življenja. Predvsem prehodi iz mladosti $v$ odraslost postajajo nejasni in fleksibilni, kar spreminja tudi obdobje odraslosti. Posledično je odraslost izgubila mnogo svojih stabilnih struktur vlog in tradicionalnih pomenov ter postaja vse bolj psihološki pojav. Vse to pa seveda pomeni, da imajo zdaj odrasli opravka s ključnim identitetnim delom, prej rezerviranim za obdobje mladosti. Tu ima pomembno vlogo izobraževanje odraslih, ki je postavljeno pred nove izzive in naloge. Poleg izobraževanja za delo (dokvalifikacije, prekvalifikacije) ima izobraževanje odraslih vedno bolj pomembno socialno funkcijo (socialno in tehnološko vključevanje, pridobivanje novih socialnih kompetenc za razumevanje družbenih dogajanj) in posebej psihološko funkcijo (razvoj »identitetnih kapitalov«, potrebnih za suvereno odraslo življenje v sodobnih življenjskih razmerah).

Ključne besede: individualizacija, prehod v odraslost, identitetni kapital, izobraževanje

\section{THE ROLE OF IDENTITY CAPITAL IN THE DEVELOPMENT OF ACTIVE ADULTHOOD IN GLOBALISED SOCIETIES - ABSTRACT}

Discussing the effects of globalisation on the changes in life cycles, the article departs from the thesis that the individualisation of the life course requires people to be better prepared in terms of responsible planning of their lives. The transitions from youth to adulthood in particular are becoming ambiguous and flexible, which in turn brings changes to the period of adulthood. As a result, adulthood has lost many of its stable roles and traditional meanings and is increasingly becoming a psychological phenomenon. Of course, all of this means that adults now have to deal with crucial identity work that before was reserved for the period of youth. Here, adult education plays an important role and faces new challenges and tasks. Besides education for work (additional training and retraining) adult education plays an increasingly important social (social and technological inclusion, acquisition of new social competences to understand social developments) and especially psychological function (the development of "identity capital" necessary for an independent adult life in late-modern life circumstances).

Keywords: individualisation, transition to adulthood, identity capital, education

Red.prof.dr. Mirjana Ule, Fakulteta za družbene vede Univerze v Ljubljani, mirjana.ule@fdv.uni-lj.si 


\section{UVOD ALI KAKO RAZUMETI GLOBALIZACIJO}

Če hočemo razmišljati o globalizaciji, se moramo znebiti dveh mitov. Prvi pravi, da naj bi bila globalizacija nekaj novega, drugi, da naj bi bila neizogibna, oba pa nas vlečeta v nejasno in zato še toliko trdnejše prepričanje, da naj bi bila globalizacija posebnost in hkrati neizogibnost naše dobe. V teoriji nikoli ne začenjamo iz nič in tudi o globalizaciji je teorija povedala že marsikaj, celo še preden smo uvedli pojem. Razlog je preprost. Globalizacija izhaja iz sistemske logike kapitalizma. V tem smislu je sistemsko nujna, odkar obstaja in vse dokler traja kapitalizem (Močnik, 2009). Prav zato pa je v okviru te sistemske »nujnosti« možnih več različnih »politik globalizacije«. Globalizacija, ki jo doživljamo zdaj, je neka posebna globalizacija, tista, ki jo uveljavlja neoliberalna politika ZDA, Evropske unije in drugih velesil po svetu (Krašovec, 2016).

Globalizacija seveda prinaša s seboj nove izzive in predvsem nova tveganja. Gre za nove delitve in nove alternative soodvisnosti v svetu. V klasični moderni je veljalo, da obstaja le ena pot do stabilnosti odnosov na vseh ravneh: ravnotežje nadvlade in odvisnosti. Najpomembnejša predstava, povezana s pojmom globalizacije, pa je nedoločena zaznava samodejnosti svetovnega dogajanja, odsotnosti centra, nadzornega mehanizma, vodilne skupine, upravljavskega biroja (Beck, 1998). Gibljivost globalnih financ, informacij in njihova neomejena svoboda sta povezani s politično fragmentacijo, razkosanjem svetovne scene. Pri gospostvu gre vedno za to, da si močnejši pridobi zase čim več gibanjske svobode in igralnega prostora. Zdi se, da politična »tribalizacija« in ekonomska globalizacija nimata različnih ciljev ali da sta v vojni, zdi se, da sta zelo tesno povezani.

Predvsem se je v sodobnih družbah zgodil premik od dominacije klasičnih industrij k dominaciji servisnih storitev, ali kot temu nekateri pravijo, premik od fordistične k pofordistični industrijski strukturi. V fordistični eri je obstajala velika potreba po manj kvalificirani delovni sili. Ob prehodu v pofordistično družbo ob koncu preteklega stoletja se je to hitro spremenilo. Velike industrijske obrate so zamenjale manjše delovne enote, ki so terjale fleksibilno specializacijo, vse več dela za določen čas in začasnih zaposlitev (Virno, 2003). Te spremembe so zahtevale višjo izobrazbo in nove vrste spretnosti, kar pomeni, da se je podaljšal čas prehoda iz izobraževanja $\mathrm{v}$ delo. Ta prehod je postal tudi zelo raznolik. Nezaposlenost pa je ob tem stalni, normalni spremljevalec te tranzicije. To pa ne pomeni, da sta tveganje in negotovost enakomerno porazdeljena. Prav nasprotno, vseskozi sta bila močno slojno in razredno specifična. A ustvarila se je iluzija individualnosti, ki je podlaga za epistemološko zmoto pozne moderne.

Pojem globalizacija se razlikuje od pojma univerzalizacija. Razlika je konstitutivna za moderni diskurz, vendar se znova in znova pozablja. Tako kot pojmi civilizacija, razvoj, konsenz, konvergenca in mnogi drugi iz diskusij in diskurzov zgodnje in klasične moderne je pojem univerzalizacija nabit z namero, odločitvijo, željo, upanjem narediti svet boljši za vse ljudi, ustvariti za vse enake življenjske pogoje. Nič od tega ne vsebuje pojem globalizacija. Globalizacija se ne nanaša na to, kaj želimo ali lahko storimo, ampak predvsem na to, kaj se nam vsem dogaja (Beck, 1998). Nahaja se onstran vsakega planiranja in 
organiziranja delovanja. Temeljne značilnosti nove globalizacije Manuel Castells (1997) označuje s konceptom »mrežne« družbe. Za novo obliko družbene organizacije, razpršeno širom po svetu, je po Castellsu značilna ambivalentnost oziroma kontradiktornost: ustvarja izobilje in revščino, spodbuja inovativnost in upanje, sproža pohlep in solidarnost, hkrati pa povzroča stisko in spravlja $\mathrm{v}$ obup. Te kontradikcije na eni strani spodbujajo kozmopolitizem in svetovno mreženje, po drugi strani pa prenašajo odgovornost za življenje in okolje na posameznika in posameznico.

Globalizacija (v dobro kapitala) in informatizacija, ki se dogajata v prepletenih mrežah kapitala, tehnologije in oblasti, povečujeta produktivne zmogljivosti, kulturno ustvarjalnost in komunikacijski potencial. Hkrati pa pospešen zgodovinski tempo in abstraktnost oblasti razkrajata obstoječe mehanizme družbene kontrole in politične reprezentacije. Informacijska tehnologija in restrukturiranje kapitalizma imata ključno vlogo v globalizaciji strateško odločilnih ekonomskih aktivnosti, mrežnih organizacijah, spremenjenih pogojih na trgu delovne sile, ki zahteva fleksibilnost zaposlitve in jo hkrati destabilizira (Castels, 1997). Protislovnosti procesov globalizacije izhajajo torej iz konfliktne dinamike dveh svetovnih redov: enega, ki se utrjuje od zgoraj in uveljavlja svojo dominacijo na podlagi gospodarske in politične moči maloštevilnih nosilcev kapitala, moči in oblasti, in drugega, ki izhaja iz emancipacijske usmeritve posameznikov in skupin pri uveljavljanju demokratizacije in socialne pravičnosti.

To opazimo že, če upoštevamo tipično asimetrično prerazporeditev kapitalov in socialnih stisk. Medtem ko se je v klasični moderni razmerje med kapitalom in delom oziroma razmerje med kapitalom in revščino razvijalo sočasno in pogojno rečeno »simetrično«, namreč kot razredna delitev in razredni konflikt na ravni držav, se $\mathrm{v}$ poindustrijski moderni kapitali in družbeno bogastvo izrazito globalizirajo, medtem ko se socialne stiske in beda izrazito lokalizirajo. Po Baumanu je to povezano $\mathrm{z}$ »izginjanjem dela«, tistega klasičnega izvrševalnega dela, ki terja vse manj človeške delovne sile. Tako se na eni strani globalizirajo različne oblike svobode in delovanja, na drugi strani pa se združujejo oblike nesvobode, a to na lokalni ravni (Bauman, 1998). Lahko bi rekli, da je globalizacija svetovni proces nove stratifikacije, $\mathrm{v}$ poteku katere nastaja nova svetovna sociokulturna hierarhija, ki se samoreproducira.

Ta dva pola nastajajoče hierarhije, vrh in dno, se drastično razlikujeta, predvsem v uporabi prostora in časa. To razlikovanje je tako veliko, da nekateri avtorji že govorijo o ljudeh dveh svetov. Prostor je za bogate (ljudje prvega sveta) izgubil omejujoče značilnosti. Ljudje prvega sveta lahko prečijo tako njegove realne kot virtualne poti, medtem ko je za revne realni prostor vedno ožji in bolj omejen (Bauman, 1998). Ko je enkrat kapital neodvisen od prostora, ne potrebuje nobene mobilne delovne sile več. Pritisk, da bi porušili še zadnje preostale ovire, ki so se uprle svobodi denarja in z denarjem proizvedenih stvari in informacij, sovpada s pritiskom, da se izkopljejo novi prepadi in postavijo novi zidovi (protimanjšinski, protimigrantski, protibegunski). Polarizacija sveta in prebivalstva globalizaciji ni tuja, ni njen moteči vpliv, ampak je njen učinek. 
Razcep med revnimi in bogatimi ni niti nov niti začasen, tak, ki bi lahko izginil z danes na jutri. Novo je predvsem to, da ta razcep še nikoli ni bil tako nepresegljiv. Je razcep med dvema, ki nimata več ničesar skupnega. Ekonomsko ogrožen človek je v sodobnih individualiziranih družbah ogrožen tudi v vseh svojih socialnih odnosih. Zato je vse bolj globalno socialno izključen (Beck in Beck-Gernsheim, 2002). Individualizirano revščino označujejo pretežno tiste poteze, ki se lepijo na človeka kot njegove osebne napake in pomanjkljivosti, ki jih človek ponotranji in tako še bolj poglobi izkušnjo svoje življenjske odpovedi, kot so občutki sramote in osebne krivde za svoj neugodni življenjski položaj. Revni tako ostajajo brez ekonomskega, socialnega, kulturnega in psihološkega kapitala, s katerim bi se lahko uprli potiskanju na družbeni rob. Zato so »novi revni «globalno socialno odvisni, obenem pa tudi globalno izločeni iz večinske družbe in kulture.

\section{SPREMEMBE ŽIVLJENJSKIH POTEKOV V POGOJIH GLOBALIZACIJE}

Globalizacija torej prinaša nove izzive in predvsem nova tveganja tudi $\mathrm{v}$ življenjskem poteku ljudi. Obstajata dve vrsti pravil, s katerimi moderne države upravljajo življenja ljudi: pravila, ki urejajo človekovo življenje na podlagi kronologije življenjskih dogodkov (starostna organizacija življenja in družbe), ter pravila, ki upravljajo dodeljevanje statusov in povezave med njimi na podlagi izobrazbenih dokazil in profesionalnih nazivov. Časovni potek življenja služi kot regulator napredovanja ljudi v družbenem prostoru in času, je časovna organiziranost celotnega prostora, v katerem poteka naše življenje. Časovni potek življenja ne glede na družbenozgodovinske okoliščine pomeni pot posameznice ali posameznika od rojstva do smrti. Pojem poti se tu nanaša na življenjsko linijo ali biografijo (Heinz, 1997).

Življenjski potek je glavna institucija socializacije, ker določa normativni okvir, ki daje smernice tako za posamičen biografski potek kot za družbeno uvrščanje posameznic in posameznikov. Deluje na presečišču treh časovnih dimenzij: biografskega, družbenega in zgodovinskega časa. Če so vzorci življenjskih potekov rutinizirani in se opaža malo odklonov od predpisanih standardov, rutin in tradicionalnih norm, jim rečemo »standardni« ali »modalni« življenjski poteki (Hagestad, 1997). Modalni življenjski poteki imajo dvojni pomen: po eni strani konstituirajo družbeno priznane in sprejete biografije posameznikov, jim dajejo družbeno podporo in odobravanje ter jih varujejo pred negotovostmi in tveganji še nepreizkušenih življenjskih potekov. Obenem pa jih omejujejo predvsem v njihovi inovativnosti in ustvarjalnosti ter zmanjšujejo avtonomnost življenjskega poteka.

Tradicionalni življenjski potek sestavljajo tri dejavnosti: izobraževanje, zaposlitev (delo) in upokojitev. Te dejavnosti so bile vezane na določena življenjska obdobja, ki so si sledila drugo za drugim (izobraževanje $\mathrm{v}$ otroštvu in mladosti, delo $\mathrm{v}$ odraslosti in upokojitev $\mathrm{v}$ starosti). Ta standardizacija poteka je služila kot vodilo za urejanje družbe in življenja posameznikov. Vsako obdobje je vsebovalo posebna pričakovanja pravic in dolžnosti. V času visoke standardizacije življenjskih potekov lahko ljudje racionalno ocenijo svoje življenjske priložnosti in načrtujejo prihodnji potek življenja. To se je zgodilo v razvitih 
državah v drugi polovici 20. stoletja. V okoliščinah visoke standardizacije življenjskih potekov so lahko ljudje ponotranjili in spoštovali družbene omejitve, ki so zakodirane v institucionaliziranih tirnicah življenjskih potekov (Ule, 2008).

Te ugotovitve so dokaj dobro veljale nekako do devetdesetih let prejšnjega stoletja. Po tem obdobju zaradi vrste družbenostrukturnih in kulturnih sprememb, ki smo jih označili kot globalizacija, začne standardiziranje življenjskih potekov upadati. Zaradi sprememb na trgu dela, opuščanja ekstenzivnega zaposlovanja so prehodi iz izobraževanja v delo postali problematični. Ti oteženi prehodi delujejo kot bumerang tudi na izobraževalni sistem. Odpravlja se povezanost prej dobro utrjenih povezav med izobrazbeno ravnijo in poklicnimi priložnostmi. Investicije v izobraževanje tako postanejo dvoumne, kajti bodoči dobiček od izobraževalnih naporov je postal vse manj napovedljiv (Côté in Allahar, 1994). Po drugi strani je postala za mlade investicija v višje oblike izobraževanja družbena nujnost. To pa vodi do podaljševanja šolanja in do večje individualizacije delovanjskih perspektiv za posameznike ter večje tekmovalnosti med vrstniki za čim boljši šolski uspeh, spričevala, diplome.

Individualizacija življenjskih potekov je eden od osrednjih pojmov, ki so jih v minulih dveh desetletjih razvili družboslovci, da bi razložili strukturne spremembe v življenju ljudi v sodobnih globaliziranih družbah. Z njim se poskušajo zajeti novi načini in institucije socializacije posameznic in posameznikov. Ne gre za normativen pojem, kjer bi šlo za vodenje ljudi k na primer bolj samostojnim načinom življenja, temveč za teoretičen opis dejavnikov, ki v sodobnih družbah oblikujejo tako družbenostrukturalno kot subjektivno raven sprememb (Baethge, 1996; Beck in Beck-Gernsheim, 2002). To ni niti enostransko pozitiven pojem, ki bi odpiral možnosti emancipacije, niti enostransko negativen, ki bi na primer zajemal procese osamitve, privatizacije, narcisističnih patologij. Obsega prav ambivalentnost družbenih in psiholoških procesov in struktur, ki jih proizvaja nova faza modernizacije.

Tvorci teorije individualizacije slednjo razlagajo kot posledico globalizacije življenjskih potekov, ki vključuje dinamizacijo in pluralizacijo življenjskih pogojev, vzorcev in stilov (Bauman, 2001; Beck in Beck-Gernsheim, 2002). Po njihovem mnenju individualizacija vključuje tri poglavitne družbenostrukturalne procese:

- povečanje izobrazbenih možnosti in izbir, razvoj novih tehnologij, novih oblik komuniciranja, posledično tudi razvoj novih družbenih, kulturnih pristojnosti in kapitalov,

- povečanje družbene in prostorske mobilnosti prebivalstva, povezane s spremembami $\mathrm{v}$ poklicni strukturi, razširitvijo različnih servisnih in storitvenih dejavnosti in ustanov, intenzivno urbanizacijo, vse večjo udeleženostjo žensk na trgu dela,

- povečanje refleksije in načrtovanja svojih življenjskih poti in možnosti, dvom o tradicionalnih življenjskih in vrednotnih usmeritvah in življenjskih poteh ter iskanje samostojnih rešitev življenjskih vprašanj.

Individualizacija pomeni preobrat od prevlade vnaprej določenih razrednih, slojnih, spolnih, kulturnih identitet k vse bolj pluralnim, posamično določenim, začasnim in relacijsko 
oziroma odnosno zastavljenim življenjskim načrtom. S pojmoma izbira in individualizacija mislimo na procese in izkušnje, za katere je značilno zmanjševanje vloge kolektivnih pripadnosti, kot so razredna pripadnost, spolne vloge, generacijska zavest, na račun krepitve lastne odgovornosti, samostojnih odločitev. Posameznik oziroma posameznica in njegovo oziroma njeno vsakdanje življenje sta tako postala strateški cilj in strateško izhodišče produkcije in reprodukcije sodobnih razvitih družb. Medtem ko je bil v industrijski moderni posameznik družbeno pomemben le kot nosilec razredno-slojnih, generacijskih in spolnih družbenih vlog in identitet, zdaj postaja pomemben on sam kot oseba s svojimi vsakdanjimi navadami, hotenji, imaginacijami, strahovi.

Sodobna tržna družba izkorišča te osebne potenciale v sferi produkcije, menjave in potrošnje, $v$ javnem in zasebnem življenju in motivira ljudi, da zavestno in načrtno gojijo in izkoriščajo te potenciale pri iskanju najboljših odločitev, izbir. Zato individualizacija življenjskega poteka zahteva večjo pripravljenost za sprejemanje tveganih odločitev v poslovnem in vsakdanjem življenju, sposobnost ljudi, da »poskrbijo sami zase«. Kot pravi Richard Sennett (1999), je klasična socialna politika hotela vnesti varnost v tvegane življenjske situacije, kakršne so denimo starost, bolezen, brezposelnost. Nova socialna politika pa bo morala več pozornosti in sredstev nameniti tveganim prehodom; ljudem, ki so v obdobju prehoda iz šolanja v poklic, ki so v obdobju prehoda iz nezaposlenosti v zaposlitev in podobno. Gre za pomoč pri iskanju ustreznega ravnovesja med časom prezaposlenosti in časom brezposelnosti, ravnovesja med javnim in zasebnim življenjem.

V fleksibilnem in individualiziranem svetu poindustrijske moderne so razmere za vzpostavitev ravnovesij ugodnejše kot $v$ režimu togih časov in struktur, pa vendarle to ne zmanjša tveganj in negotovosti. Zato individualizacija življenja prinaša predvsem bolj ali manj iluzoren vtis emancipatornega procesa, saj v resnici povzroča številne pritiske in strese na ravni realnega vsakdanjega življenja, med katerimi prevladujejo stresi zaradi potrebe po nenehnih izbirah in zaradi občutka negotovosti, tesnob glede pravilnosti odločitev in izbir. Sodobni kapitalizem živi prav od izkoriščanja individualnih potencialov za samomotivacijo in samoorganizacijo življenja. Iznašel je veliko bolj zvit način izkoriščanja ljudi kot klasični ali monopolni kapitalizem, namreč izkoriščanje samoodgovornosti ljudi za svoj življenjski potek namesto neposrednega izkoriščanja njihove delovne sile (Beck, 1998). Zato so danes zaposleni pripravljeni delati bolj trdo, predvsem pa bolj zagreto, kot so to počeli tradicionalni mezdni delavci.

Individualizacija življenjskih potekov pomeni prelaganje družbenih zahtev, odgovornosti, nadzorovanj in urejevanj na posameznike. Gostota teh urejevanj v sodobnih globaliziranih družbah je zelo velika, njihov skupni učinek pa kompleksnost, podobna labirintu, ki nas spremlja dobesedno od rojstva do smrti. Celotna družba, gledano $s$ tega vidika, postane nekakšna individualna spremenljivka. Družbene determinante se v tej optiki kažejo kot okoljske spremenljivke, ki jih posameznik in posameznica s svojimi željami, pričakovanji, fantazijami lahko izkoristita ali pa ne (Beck in Beck-Gernsheim, 2002). Vendar to ne pomeni, da se ljudje zato osamosvajamo od zunanjega nadzora in družbenih omejitev. Individualizirani posamezniki so vsestransko odvisni od trga dela, izobraževalnih in socialnih 
ustanov, porabe, pravnih uredb, od prometnih ureditev, urbanističnih rešitev, mode, od zdravstvenih, psiholoških, pedagoških nasvetov.

Individualizacija zato ne pomeni nujno povečanja posameznikove svobode izbire in odločitve, temveč predvsem spremembo načina družbenega nadzora. Problem individualizacije je torej ta, da ljudje samostojnost v odločanju, ki jo zahtevajo procesi individualizacije, nadomeščajo z nekakšno simulacijo samostojnosti. To jih dela dejansko bolj odvisne od družbenih struktur in mehanizmov, kot je to veljalo za posameznike v tradicionalni industrijski družbi. Tako se pritisk k individualizaciji življenjskega poteka sprevrača v svoje nasprotje, v vse večjo odvisnost ljudi od globalnih družbenih institucij, ki jim ponujajo »podporo«, še bolj pa jih zavajajo v tržno pogojene in vodene vzorce življenja. Elektronski mediji do nepredstavljivih razsežnosti razširjajo polje informacij in nas vpletajo v svoje mreže. Vse bolj razširjene tehnike delitve in proizvodnje blaga so omogočile eksplozijo storitev in potrošniških izdelkov, ki smo jim izpostavljeni ves čas.

\section{NOVA VLOGA ODRASLOSTI V SODOBNIH GLOBALIZIRANIH DRUŽBAH}

Globalizacija in individualizacija življenjskega poteka se kažeta predvsem skozi naslednje značilnosti: menjava življenjskih prostorov, fleksibilnost zaposlitve, mešanje več življenjskih perspektiv v eni biografiji, novo razumevanje mobilnosti - virtualna mobilnost, ne zgolj realna mobilnost med različnimi prostori, družbenimi ravnmi, državami in tako dalje. Danes si lahko gibljiv, ne da bi se ti bilo treba fizično premakniti iz svojega kraja, na primer s sodelovanjem $\mathrm{v}$ različnih virtualnih svetovih s pomočjo novih informacijskih tehnologij, sodelovanjem $v$ različnih oblikah potrošnje.

Zaradi preoblikovanja podjetij in zmanjševanja števila zaposlenih se povečuje usmeritev k epizodičnim vzorcem dela in zaposlitve, to pa vpliva na druge biografske odločitve posameznic in posameznikov (Kohli, 1994). Strategije delovne lojalnosti zaposlenih in lojalnosti do zaposlenih, notranji trg dela in načelo senioritete, ki so omogočali zaposlitvene kariere in stabilne zaposlitve v klasični moderni, so nadomestile strategije zniževanja stroškov. Te ustvarjajo verige nestandardnih zaposlitev, zgodnje upokojitve ali pa prožne (beri) prekarne zaposlitve. Pogled na vse večjo prožnost upokojitev kaže, da je načelo polne in trajne zaposlitve do upokojitve vse bolj šibko. Ljudje so vse bolj prisiljeni obnašati se kot krošnjarji, ki svoje spretnosti ponujajo delodajalcem.

Pomembna komponenta sodobnega življenjskega poteka je čas. Vse se spreminja zelo hitro. To zmanjša napovedljivost razvoja in prihodnosti. Življenjski poteki se zato nenehno prilagajajo spremenjenim okoliščinam. Tudi prehodi niso več predvidljivi, kot so bili v preteklosti, ampak morajo biti izpogajani z institucijami, skozi katere prehajajo ljudje. Zaporedje in načrtovanje prehodov med otroštvom in odraslostjo se fragmentirata. Prav tako se fragmentira prehod iz odraslosti v starost. V nekatere dejavnosti, značilne za odrasle, vstopijo mladi zelo zgodaj, že na koncu otroštva, na primer v potrošništvo. Zabrisujejo se meje med mladostjo in odraslostjo, med pripravo na aktivno življenje in samim aktivnim življenjem. Obdobje mladosti ni več ključno za oblikovanje osebnosti. Mladi odlagajo 
odločanje, ki naj bi ga opravili v prehodu oziroma v mladosti, torej v omejenem časovnem obdobju, in ga prenašajo v odraslost. Obenem pa se dogaja juvenizacija odraslosti in družbe; dejavnosti, nekoč značilne za mladost, se razširjajo v odraslost (Ule, 2008).

Strokovnjaki so si že enotni v tem, da je odraslost izgubila mnogo svojih stabilnih struktur in tradicionalnih pomenov ter postaja vse bolj psihološki fenomen. Pomen in prepoznavnost so izgubili tudi družbeni označevalci, ki so včasih omogočali prehod v odraslost. Zato ni več jasne opredelitve odraslega in odraslosti. Ta je zasnovana bolj na posamičnih preferencah kot na družbenih normah. Eden od odzivov, ki vzbuja strokovno pozornost, je, da poskušajo odrasli ohranjati mladost, kolikor dolgo je možno, tako z videzom kot obnašanjem, da doživijo toliko užitkov, kot je možno, in da ohranjajo življenjske poteke in možnosti odprte. Ali kot trdi Christopher Lasch, da je ekonomskega človeka zgodnje moderne zamenjal psihološki človek (Lasch, 1979, 2012). Normalizacija narcisizma je mogoče najbolj očitna dramatična sprememba v zahodnih družbah. Lasch v zvezi s tem govori o hedonizmu brez sreče, narcističnem iskanju samozadovoljstva, jemanju, ne da bi bili pripravljeni dajati.

Čeprav živimo precej dlje, se izkazuje, da vse več ljudi ne odraste v tradicionalnem pomenu besede, kot se to navadno razume. Vzrokov za to je več. Predvsem družbene, ekonomske in tehnološke spremembe so povzročile, da je izjemno težko odrasti tako, kot je bilo to običajno še pred nekaj desetletji. Življenjske poti postajajo nelinearne, kar pomeni, da lahko skoraj v vsakem trenutku življenja »začneš znova«; vrneš se v izobraževanje, znova začneš družinsko življenje ali poklicno kariero. Z drugimi besedami, tudi v odraslosti se odločaš o stvareh, o katerih se »normalno « odločaš, ko si mlad. Značilne zaposlitve odraslih in mladih so vse bolj pomešane: vse več šolarjev in študentov dela, odrasli pa se vračajo v izobraževalne procese. Šolanje in izobraževanje tako nista več vezani na odraščanje in mladost. Svetova izobraževanja in dela sta vse manj ločena in nista več nujno zaporedna.

Tako analiza podatkov raziskave Slovensko javno mnenje za zadnjih 15 let kaže (Graf 1), da se tako ali drugače izobražuje med 30 in $40 \%$ anketiranih v Sloveniji vseh starosti.

Analiza podatkov ne zaznava razlik po spolu, so pa razlike po starosti (Graf 2) in izobrazbi anketiranih (Graf 3).

Najbolj močno so v dodatno izobraževanje vključeni stari med 31 in 45 let. Kar $52 \%$ anketiranih te starosti se je udeležilo kake izobraževalne dejavnosti v letu 2016. V starostni kategoriji med 19 in 30 let je tistih, ki so se udeleževali dodatnega izobraževanja, 50 \%, v starostni kategoriji med 46 in 60 let se jih kakorkoli izobražuje $38 \%$, v kategoriji nad 60 let pa $8 \%$.

Glede na izobrazbeno strukturo anketiranih se dodatno izobražuje največ tistih z višjo in visoko izobrazbo (59 \%), najmanj pa se dodatno izobražujejo tisti z osnovnošolsko (13\%) in poklicno izobrazbo (21\%).

Odraslost torej danes pomeni reprezentacijo tega, kako ljudje upravljajo negotovosti in možnosti sodobnega sveta, v katerem so postali odgovorni za svojo usodo in lahko 
Graf 1: Ali ste se v zadnjih 12 mesecih udeležili kakšnega tečaja, predavanja ali konference, da bi izbolišali svoje znanje ali delovne veščine $(v \%)$ ?

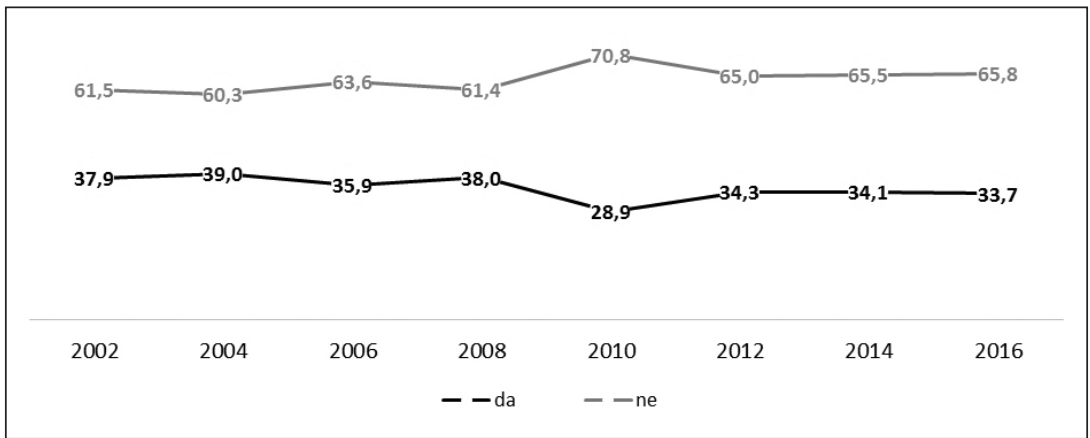

Vir: Kurdija in Malnar, 2017.

Graf 2: Udeležba v izobraževanju v zadnjih 12 mesecih po starostnih kategorijah ( $\%$ )

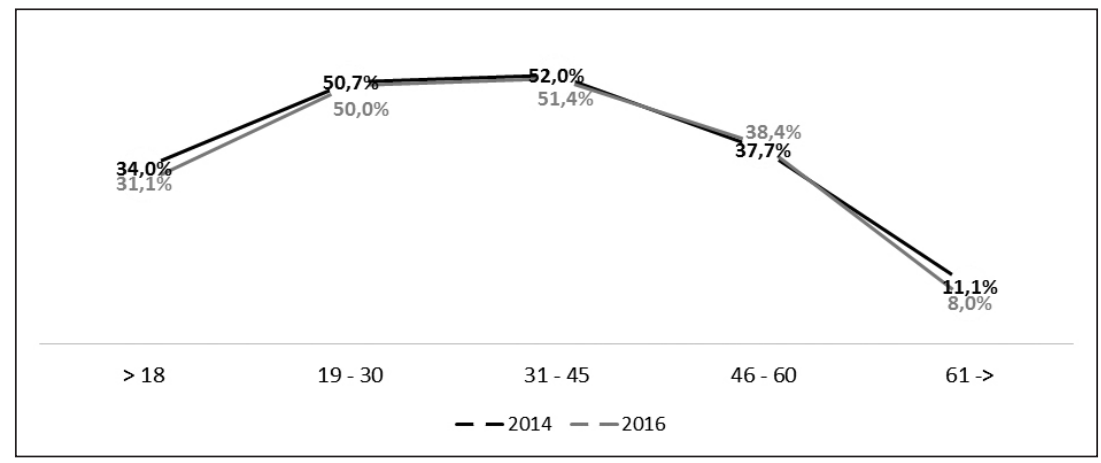

Vir: Kurdija in Malnar, 2017.

Graf 3: Udeležba v izobraževanju v zadnjih 12 mesecih glede na izobrazbeno strukturo anketiranih (v \%)

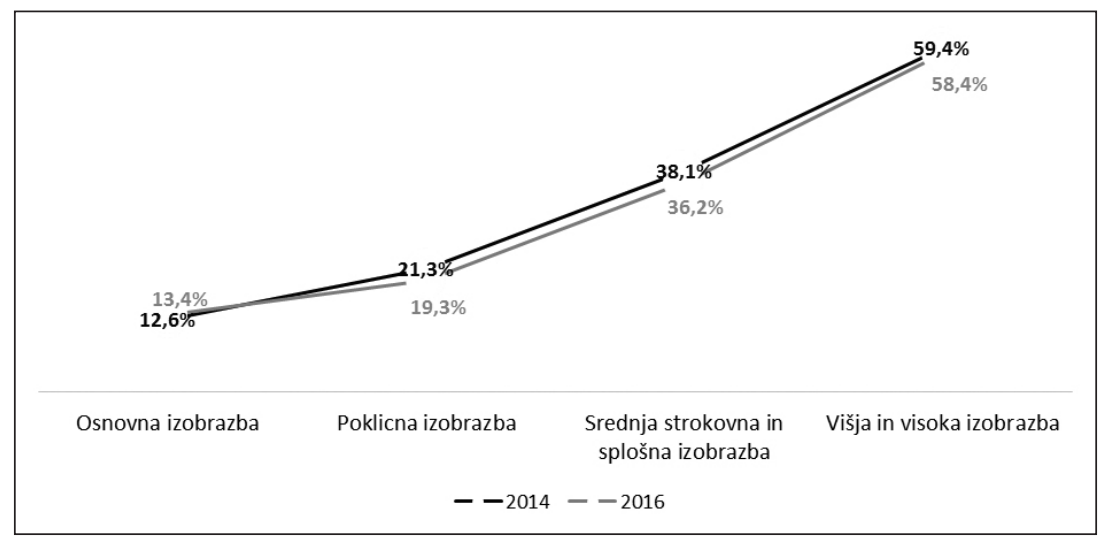

Vir: Kurdija in Malnar, 2017. 
izbirajo, kateri avtoriteti, vrednotnemu sistemu bodo sledili. Ob tem pa niso razbremenjeni odgovornosti za razvoj skupnosti in družbe (Côté, 2000; Ule, 2008). Pri odgovorni odraslosti gre za združevanje dveh moralnih naravnanosti: moralne odgovornosti skrbi za druge in univerzalistične etike pravičnosti. Ti dve moralni usmeritvi je prva natančno raziskala in opisala Carol Gilligan (1982). Po njenem mnenju je problem sodobnih družb, da sta ti dve moralni usmeritvi postavljeni druga proti drugi in spolno kontaminirani. Moralna usmeritev »skrbi za druge « se pripisuje ženskam in je bila v moderni prav zaradi tega podcenjena ter podrejena »moški usmeritvi« univerzalne moralne pravičnosti ne glede na posledice. Že Gilliganova poziva, da je tako za odgovorno odraslost kot za temeljni etični razvoj sodobne družbe pomembna združitev obeh.

Côté (2000) pa celo meni, da bi kritična masa odraslih, ki bi razvili obe naravnanosti, lahko delovala kot katalizator v prizadevanjih za odpravljanje problemov v odraslosti, ki jih ustvarjajo sodobne kapitalistične družbe. Ob tem ugotavlja, da so šle zahodne družbe v minulih desetletjih v smer enostranskega razvoja nedozorele odraslosti, zazrte vase, ter zanemarile pomembne probleme skupnosti in odgovornosti odraslosti. Côté vidi vzroke v sodobni potrošniški družbi, ki ima interes, da se povečuje populacija nezrelih odraslih s šibkim jazom ter dobro razvitimi nezavednimi impulzi, predvsem težnjo po neposredni in takojšnji zadovoljitvi želja. Ne le da na takšno populacijo laže vplivamo s tržnimi ponudbami, je tudi manj odporna proti različnim oblikam očaranja $\mathrm{z}$ obljubami in navideznim zadovoljevanjem želja.

Enega od načinov reševanja tega problema ponuja model pluralizma karier, »časovnih rezin « v načrtovanju življenjskega poteka v pozni moderni. Kariere so postale pomembne, potem ko za načrtovanje in razreševanje življenjskih dogodkov niso več zadoščali rojstvo, domača socializacija in družbeni sloj (Luhmann, 1994). Kariera v pomenu, kot se je uporabljala v klasični moderni, zaznamuje menjave poklicnih položajev posameznika v nekem organiziranem družbenem sistemu. V pozni moderni se pojem kariere razširi. Kariera je postala zaporedje selektivnih dogodkov, ki jih izbere človek sam in ki vodijo k doseganju začasnega življenjskega cilja in samouresničevanja. Postala je oblika avtopoetskega razmerja, ki se nanaša samo nase ter se s tem tudi ohranja in razvija. Sestavljajo jo dogodki, ki sodijo k njej zato, ker pospešujejo in s tem omogočajo druge dogodke, ki tudi sodijo k njej. Pomeni lahko na primer načrtovanje izobraževalne poti, vstopanje in izstopanje iz izobraževanje (izobraževalna kariera), da se poveča zaposljivost posameznika ali da se okrepijo identitetni kapitali človeka.

\section{VLOGA IDENTITETNIH KAPITALOV V RAZVOJU AKTIVNE ODRASLOSTI}

Prav zaradi individualizacije in globalizacije življenja izginja predstava o zaključeni, dobro zamejeni identiteti posameznika, ki je vezana na definiran »domači kraj«. Noben prostor ni več »moj«, ni več prednostni prostor mojega življenja, temveč nastaja mreža življenjskih prostorov posameznika, ki ustrezajo različnim »svetovom «, med katerimi se gibljemo. Tako delno destandardiziranje življenjskih potekov v sodobnih razvitih 
družbah širi obseg dogodkov, ki so potencialno dostopni ljudem, in obenem zožuje verjetnost za oblikovanje dolgoročnih, trajnih pričakovanj. Prispeva k oblikovanju močno individualnih, začasnih in fluidnih identitet ter podpira delovanje, usmerjeno v trenutne zadovoljitve in manj $\mathrm{v}$ prihodnost. Te spremembe delujejo tudi na odrasle, tako da so prisiljeni prenavljati in izboljševati svoja poklicna znanja in spretnosti ter obnavljati in krepiti samopodobo.

Da bi pojasnili spremembe v identitetnih strukturah, se avtorji naslanjajo na koncept kulturnega kapitala Pierra Bourdieuja (1985). Sodobne družbe po njegovem označuje premik med različnimi vrstami kapitala: ekonomskim, kulturnim in socialnim, pri čemer ekonomski kapital zajema tradicionalni kapital v obliki proizvajalnih sredstev, finančnih virov in institucij, ki obvladujejo gospodarstvo, kulturni kapital pomeni zbrano kulturno bogastvo družbe in izobrazbeni potencial ljudi, socialni kapital pa označuje značilnosti socialnih struktur, socialne odnose in omrežja.

Vse te oblike kapitala pomenijo izvore družbene moči. In izvori moči se lahko med seboj krepijo: ekonomski kapital lahko uporabimo za povečanje kulturnega kapitala, na primer za izobraževanje ali nakup kulturnih dobrin. Bourdieu (1985) je poudaril, da je za ljudi pomembno, kakšen kapital imajo na voljo v družbi. Pri tem je uvedel nove razlike med izvori kapitalov, ki služijo temu, da neka družbena skupina potrdi ali pa spremeni svoj položaj v družbenem in kulturnem prostoru. Prav tako je pomembna relativna veljava posamezne vrste kapitala v danem družbenozgodovinskem obdobju. Kulturni kapital si ljudje pridobivajo $\mathrm{v}$ procesu izobraževanja, skozi naslove in priznanja v prostočasnih kulturnih in športnih dejavnostih, prek medijev. Pomemben izvor kulturnega kapitala je danes industrija novih tehnologij. Drug izvor kulturnega kapitala so tudi osebne dejavnosti posameznikov na področjih oblikovanja okusa, življenjskega stila, telesne samopodobe, čustev in družbenega udejstvovanja.

Côté je na podlagi Bourdieujeve teorije kapitalov predlagal uvedbo pojma identitetnega kapitala, ki zajema vse kontekste, ki pomembno sodelujejo pri razvoju identitete (Côté, 2007). Côtéjeve raziskave o pomenu identitetnega kapitala kažejo, da niti zanimanje ekonomistov za človeški kapital niti zanimanje sociologov za kulturni kapital ne pojasnita osebnega in socialnega razvoja posameznika ter njegove socialne integracije. Ne en ne drug pojem nista dovolj občutljiva za kompleksnost procesa individualizacije v sodobnih družbah. Pojem identitetnega kapitala ponuja povezavo med njima in dodaja nujno potrebne psihološke in socialne vire, ki jih mora v svojem odraščanju razviti in znati uporabiti posameznik, zato da doseže polno socialno integracijo v družbo odraslih.

Posameznik na podlagi svojih kapitalskih identitetnih vložkov v prihodnost »pobira dividende « na identitetnih trgih. Da postane dober igralec na njih, mora najprej vzpostaviti stabilen občutek sebstva, tega pa podpirajo njegove socialne in tehnične spretnosti na številnih področjih dejavnosti, učinkovit vedenjski repertoar in psihosocialni razvoj ter vključenost v ključne socialne in poklicne mreže (Côté, 2007). Najuspešnejši vlagatelji v trg identitet gradijo na obeh vrstah identitetnih virov: socialnih in psiholoških (Ule, 2000). 
Côté je prve pobude za uvedbo pojma identitetnega kapitala dobil iz raziskav sodobnega množičnega izobraževanja mladih na univerzah. Pojem identitetnega kapitala mu je na primer pomagal razumeti, zakaj nekateri študentje uspevajo v svojem študiju in karieri, drugi pa ne, čeprav izhajajo iz podobnih socialnih razmer in imajo podobne intelektualne sposobnosti. Côté domneva, da imajo uspešni zadosten identitetni kapital. Raziskave o razvoju motivacije za študij pri študentih so denimo pokazale, da je razlika med aktivnimi in pasivnimi študenti pomembnejša za uspeh v študiju in življenju, kot so denimo razlike v premoženjskem položaju njihovih izvornih družin (Côté in Allahar, 1994). Côté in Levine sta identificirala dve podvrsti pasivnih študentov: študente z motivacijo, ki jo poganjajo pričakovanja staršev, in študente, ki se za neki študij odločijo preprosto zato, ker niso imeli drugih boljših možnosti. Oba motiva na splošno dajeta negativne rezultate glede pridobljenih spretnosti in dosežene stopnje študija.

Côté razlikuje med pasivno in aktivno obliko individualizacije v sodobnih družbah. Za pasivno individualizacijo je značilno, da posamezniki pasivno sledijo trendom in stilom, ki jih narekuje sodobna potrošniška družba. Tisti, ki gredo po aktivni poti, so bolj vpleteni v potek svoje osebnostne rasti in poklicne kariere (Côté, 2000). Upirajo se iskanju lažjih rešitev, ki zahtevajo le malo osebnega prizadevanja, in namesto tega raje raziskujejo svoje sposobnosti, gradijo svojo psihološko moč, krepijo kritično zavest o svetu ter razvijajo individualne pomene in smisle življenja. Te osebe ohranjajo čut za odgovorno delovanje, pa čeprav drugi okrog njih počnejo drugače. V procesu individualizacije morajo ljudje na primer določati svoje vrednote in prepričanja, skupinske pripadnosti, prostočasne interese kot tudi intelektualne in estetske preference. To vse so danes primarno naloge oblikovanja identitete.

Vse to pa pomeni, da morajo zdaj odrasli opraviti ključno identitetno delo, prej rezervirano za obdobje mladosti. Raziskovalci identitetnih sprememb v življenjskem poteku so ugotovili, da se poglavitna kriza identitete iz (post)adolescence seli v obdobje mladih odraslih (Côté, 2007). Tako klasična adolescenca dijakov kot podaljšana adolescenca študentov sta postali s stališča prehoda in odločitev neproblematični in stabilni življenjski obdobji, vezani predvsem na izpolnjevanje zahtev v izobraževalnem sistemu. Šele obdobje mladih odraslih je obdobje razreševanja temeljnih identitetnih vprašanj. Identitetno delo $\mathrm{v}$ odraslosti po težavnosti, kriznosti in pomembnosti postaja podobno tistemu v mladosti.

Novejše raziskave kažejo, da so odrasli razvili dve vrsti strategij spopadanja z identitetnimi krizami: razvojne in izogibovalne strategije razreševanja identitetnih problemov (Schwartz, Côté in Arnett, 2005). V njih ugotavljajo, da na izbiro teh strategij pomembno vpliva občutek odgovornosti za svoj življenjski potek in zaupanja $\mathrm{v}$ to, da bo odrasel človek lahko presegel ovire, ki jih doživlja. Človek z razvojno strategijo zaupa v svoje sposobnosti in moč, v identitetnih odločitvah neobremenjeno upošteva več različnih možnosti. Človek z izogibovalno usmeritvijo pa nima tega občutka, zato teži h konformnosti s socialnimi pričakovanji ali k odlaganju identitetnih odločitev in njihovemu izogibanju. Ljudje, ki sledijo izogibovalni strategiji, izkazujejo dokaj šibko samospoštovanje in samozaupanje, kažejo tudi manjšo zavezanost svojim ciljem, vrednotam in prepričanju (prav 
tam). Njihovo identitetno raziskovanje je odvisno od različnih naključij in pogosteje vodi do življenjskih zmed in zmot. Njihovi identitetni problemi se ne izražajo v sistematičnem raziskovanju dostopnih možnosti, temveč pretežno v brezciljnosti in anomiji, ki sta značilni za klasično difuzno identiteto.

Človek z razvojno strategijo nikoli ne »dokonča« svojega identitetnega razvoja, temveč ostaja stalno aktiven razreševalec identitetnih problemov. Medtem pa človek z izogibovalno strategijo teži k pasivizaciji identitetnega razvoja, na primer s tem, da fiksira svoj osebnostni razvoj, ko se prilagodi pričakovanjem staršev in socialne okolice. S tem se sicer izogne tveganjem in morebitnim bolečinam, ki bi jih prinesla soočenja $\mathrm{z}$ novimi identitetnimi problemi, vendar pri tem tvega nastanek težjih problemov in konfliktov, ki se pojavijo zaradi novih kriznih ekonomskih, socialnih in medosebnih razmer, ki terjajo od njega večjo osebnostno zrelost, nove intelektualne in emocionalne sposobnosti. Lahko govorimo o tem, da ljudje z razvojno strategijo postanejo življenjsko aktivni, medtem ko ljudje z izogibovalno strategijo postanejo življenjsko pasivni.

Človek, ki ponotranji razvojno strategijo, mora aktivirati izvore svojega identitetnega kapitala, predvsem svoj socialni in izobrazbeni (kulturni) kapital, na primer tako, da pridobi ali predloži dokazila o izobrazbi (izobrazbeni kapital), sodeluje v različnih združenjih, društvih, klubih (socialni kapital). Ta dokazila delujejo kot nekakšen potni list človeka na njegovem potovanju na druga družbena in institucionalna področja. Potrebuje jih zato, da prepriča »čuvarje« oziroma »vratarje« skupin, institucij, dejavnosti, ki jim želi pripadati, da ga spustijo vanje. Doseganje realnega ali imaginarnega članstva v takšnih skupinah je pomembno v vsakdanji mikropolitiki identitetnih pogajanj človeka $\mathrm{z}$ njegovim družbenim okoljem. Prek interakcije z drugimi in potrjevanja s strani omenjenih izvorov identitetnega kapitala človek izboljšuje svojo samopodobo in samopredstavitev, s tem pa se povečuje tudi identitetni kapital.

Poleg navedenih opaznih socialnih izvorov identitetnega kapitala obstajajo še neopazni izvori, ki so morda še pomembnejši za razvoj identitete aktivnega odraslega človeka. To so bolj psihološki dejavniki, kot so trdnost sebstva, čustvena stabilnost in senzibilnost, samoodprtost in sposobnost vživljanja, kognitivna širina, prožnost in kompleksnost, sposobnost kritičnega razmišljanja in moralne presoje ter druge značajske lastnosti, ki dajo človeku psihološko vitalnost, ter sposobnosti za uspešno razumevanje in obvladovanje socialnih, poklicnih in osebnih ovir ter priložnosti, ki jih lahko pričakuje $\mathrm{v}$ času pozne moderne (Côté in Levine, 2002, str. 145).

Neopazni identitetni viri so povezani na primer z zmožnostjo jaza za sintezo in za izvedbo, ki sta temeljni zmožnosti za varovanje psihosocialnega zdravja in psihosocialnega razvoja človeka. Lahko pripomorejo k večji notranji trdnosti osebe, ker omogočajo refleksivne odgovore in refleksivno nanašanje na socialne moči. Človek tako lahko razvije občutek avtorstva svoje biografije, odgovornosti za svoje življenjske izbire ter za ustvarjanje smiselnega in zadovoljivega življenja. Ti cilji so tudi osrednjega pomena za individualiziranje življenjske poti. Uspešna uporaba identitetnega kapitala po Côtéju (2000) ne 
pomeni podpore manipulativnim strategijam vzbujanja vtisov o sebi in varanja drugih. Nasprotno, človek uporablja svojo prožnost in osebnostno kompleksnost tako, da se lahko prilagaja večdimenzionalnim kontekstom družb pozne moderne. Identitetni kapital je torej celota moči, ne pa množica makiavelističnih trikov ali taktik strateške manipulacije s samim seboj in svetom.

\section{VSEŽIVLJENJSKO UČENJE KOT ODGOVOR NA IZZIVE GLOBALIZACIJE}

Globalizacija prinaša radikalne spremembe v življenja ljudi. Destabilizira gotovosti vsakdanjega življenja, odpira možnost za pojav nepričakovanih dogodkov, ki nastanejo kot stranski učinki tehnoloških in ekonomskih sprememb v svetu. Kot pravi Beck (2016), globaliziranega sveta ne moremo več razlagati s pojmi, kot je družbena sprememba. Po njegovem gre za preobrazbo sveta. Pri spremembah gre namreč za permanentno transformacijo, pri čemer bazični koncepti in strukture, ki jih podpirajo, ostajajo konstantni. Preobrazba, nasprotno, destabilizira te strukture. Še več, omaje družbene konstante dosedanje eksistence in razumevanja sveta ter povzroča prave eksplozije šoka. Preobrazba pomeni, da je tisto, kar je bilo še včeraj nezamisljivo, danes realno.

Spremembe na trgu dela in grožnje potencialno izključenih mladih generacij so prisilile politiko, da z različnimi izobraževalnimi ponudbami in podaljševanjem šolanja zmanjša pritisk na trg dela. Zaradi podaljševanja in razširjanja izobraževalnih procesov na celotno generacijo mladih ter drugačnih zahtev trga postaja celo potreba po starostnem segmentiranju družbe na mlade in odrasle $\mathrm{v}$ zadnjem času vse manj aktualna. Ta proces torej v svojem trendu odpravlja mladino in mladost, toda paradoksalno tako, da nekatere pomembne značilnosti mladosti razširja na vse generacije in vse življenje. Med temi so na prvem mestu potreba po vseživljenjskem izobraževanju, negotovi zaposlitveni vzorci, potreba po stalnem redefiniranju (partnerskih) odnosov in identitete. Te značilnosti so doslej pripadale predvsem mladim, danes pa si jih mora potencialno prisvojiti vsakdo, ki želi biti uspešen v sodobni tehnološko zahtevni družbi.

Opraviti imamo s starostno-zaposlitvenim paradoksom, vse večjim razhajanjem med pričakovanim trajanjem življenja in vse težjo zaposljivostjo starejših nezaposlenih. Podoben paradoks je tudi v usklajevanju delovnega in družinskega življenja. Narašča potreba po trajnem usklajevanju družinskega življenja, zaposlovanja in izobraževanja, vendar je to potrebo danes vse težje zadovoljiti zaradi vse večje prožnosti ekonomije. Potrebne bodo najbrž obsežne politične spremembe, če se bomo lotili doseganja biografske integracije zaposlovanja, družinskega življenja in izobraževanja. Obstaja že vrsta predlogov za reševanje teh biografskih zank (Ule in Kuhar, 2003):

- reorganiziranje delovnega časa oziroma zamenjava »sprinterskega« modela kariere z »maratonskim « modelom; na primer podaljševanje celotnega zaposlitvenega obdobja posameznika in krajšanje dnevne/tedenske delovne obveznosti;

- razširjanje modela vseživljenjskega učenja namesto koncentracije izobraževanja na določeno življenjsko obdobje; 
- svobodnejše, dogovorno oblikovanje delovnega časa, prožnejši sistemi tako imenovanih računov delovnega časa;

- univerzalni državljanski dohodek, ki bi ljudem ponujal vsaj minimalno socialno varnost v obdobju začasne brezposelnosti.

Ne moremo se torej več zanašati niti na temeljne gotovosti vsakdanjega sveta. To so doživetja in izkušnje, ki niso le zadeva teh ali onih skupin ljudi, to so izkušnje mnogih ljudi sedanje dobe, kar jim daje značaj splošnih izkušenj, ki zahtevajo usvajanje nekega novega znanja za obvladovanje življenja. Pri tem moramo upoštevati, da vseživljenjsko učenje ni le nekakšno trajno izobraževanje ljudi po koncu formalnega šolskega izobraževanja, ob pomoči raznih izobraževalnih institucij, učenja ob delu. Gre, kot pravi Peter Jarvis (2007), za kombinacijo več procesov, ki zajemajo tako telo kot um. Ti procesi vključujejo izkušnje iz raznih življenjskih situacij, ki jih potem človek kognitivno, emocionalno ali praktično integrira v svojo biografijo. Zato gre v vseživljenjskem učenju za stalno spreminjanje, za vedno nove izkušnje. To dogajanje je nenehno in zajema vsa življenjska obdobja. Kot rezultat globalizacije in hitrih družbenih sprememb se preprosto moramo nenehno izobraževati. Le tako se lahko počutimo doma v tem svetu, ki vnaša spremembe v vsak vidik vsakdanjega življenja.

Jarvis govori o tem, da morajo ljudje usvojiti priložnostno in samostojno učenje (Jarvis, 2007, str. 140). Prvo označuje učenje iz izkušenj, pridobljenih v dogodkih, ki so prinesli pomembne spremembe v vsakdanje življenje ljudi. Drugo pa učenje, ki ga človek izvaja v svoji režiji, običajno na neformalne načine, skozi svoje delovne izkušnje, ob prebiranju strokovne literature, $\mathrm{z}$ brskanjem po internetu in podobno. Jarvis še dodaja, da učenje $\mathrm{v}$ globaliziranem svetu ni le vseživljenjsko v smislu časovnega obsega poteka, temveč je tudi vsezajemajoče učenje $\mathrm{v}$ smislu vseh področij življenja. V vseživljenjskem učenju gre za ontološko bazo učenja, za to, kar smo in kar lahko postanemo. V vsezajemajočem učenju pa gre za učenje iz različnih vlog, ki jih prevzemamo v življenju, od koder gradimo svojo (socialno) identiteto (Jarvis, 2007, str. 154). Nekateri avtorji omenjajo še poglobljeno življenjsko učenje, ki zajema poglobljene identitetne in vrednotne vidike življenja (Belanger, 2016). Te oblike učenja ponujajo širok konceptualni okvir za razumevanje tega, kako, kje in zakaj se ljudje učijo. Vse tri vrste učenja seveda potekajo sočasno in se medsebojno prepletajo.

Če povežemo to misel s Côtéjevo tezo o ključni vlogi identitetnega kapitala pri razvoju aktivnega posameznika ali posameznice, potem lahko sklepamo, da bodo le ljudje, ki v svojem življenju uveljavljajo večinoma razvojno življenjsko strategijo, lahko izkoristili možnosti in pobude za produktivno vseživljenjsko, vsezajemajoče in poglobljeno učenje. Na drugi strani bodo ljudje, ki v svojem življenju uveljavljajo večinoma izogibovalno življenjsko strategijo, dojemali te možnosti in pobude predvsem kot prisilo k učenju. To pa pomeni, da bodo o tem, kako se bo odvijalo vseživljenjsko učenje, v velikem delu odločali identitetni kapitali, ki so si jih ljudje pridobili v življenjskem poteku. To potrjujejo tudi podatki raziskav javnega mnenja, ki smo jih predstavili v Grafu 3, o tem, kako je vključitev v dodatno izobraževanja povezana s stopnjo formalno dosežene izobrazbe. Ker pa 
je porazdelitev identitetnih kapitalov znatno odvisna od socialnega statusa oziroma razredne pripadnosti in v njej prevladujočih izobraževalnih vzorcev, je sleherno nekritično zavzemanje za vseživljenjsko učenje, za dodatno izobraževanje, za izobraževanje odraslih ideološko početje, ki poskuša obstoječe realne socialne razlike preseči s pomočjo določene izobraževalne politike.

Jarvis (2007) se te nevarnosti zaveda. Po Jarvisu na vseživljenjsko učenje močno vplivajo konkretne družbene razmere, $v$ katerih živijo ljudje in se $\mathrm{v}$ njem odzivajo na ta družbeni kontekst. Izobraževalne institucije imajo pri tem vlogo »ideoloških aparatov države « (Althusser, 1980). Zato je vseživljenjsko učenje (in podobno vsezajemajoče in poglobljeno učenje) zaznamovano z dominantnim vrednotnim in ideološkim sistemom (Jarvis, 2007, str. 146). Jarvis opozarja, da lahko zaradi tega v sedanjem globaliziranem kapitalističnem svetu vseživljenjsko učenje deluje tudi kot socializacijska agentura tega sveta. Mnoge institucije in skupnosti, kjer pridobivamo nova znanja in kjer se učimo »igrati« svoje vloge, se ujemajo z globalnim svetom sodobnega kapitalizma.

Zato nekateri kritični teoretiki izobraževanja govorijo o učenju, ki bi presegalo okvire sedanje kapitalsko motivirane globalizacije. Paolo Freire, znani brazilski teoretik radikalnega izobraževanja, na podlagi svojih negativnih izkušenj z vplivi globalizacije na brazilsko družbo na primer poziva na preseganje »bančniškega izobraževanja « $\mathrm{v}$ »izobraževanje, ki zastavlja probleme«. Bančniško izobraževanje poskuša ohranjati družbene neenakosti in razume učence kot »nevedne subjekte «, v katere se shranjujejo razne informacije, spremenjene $\mathrm{v}$ znanje, podobno kot se $\mathrm{v}$ bankah hrani denar in se spreminja v kapital. Izobraževanje, ki zastavlja probleme, po Freiru motivira ljudi k temu, da se kritično odzivajo na družbo okrog sebe in so jo pripravljeni spreminjati (Freire, 2000).

Podobno kot Freire tudi njegov kolega, brazilski teoretik izobraževanja Carlos A. Torres ugotavlja, da sedanja pretežno neoliberalno vodena globalizacija privilegira ali kar neposredno vzpostavlja določene izobraževalne politike, na primer favorizira deregulacijo javnega šolstva, podpira zasebno financiranje vseživljenjskega izobraževanja, konkurenco v posredovanju in preverjanju znanja (Torres, 2009). Tudi Torres se zavzema za emancipatorno izobraževanje, ki pripomore k osvobajanju ljudi od prisilnih oblik socializacije, in pri tem kot možen model omenja prav Freirov koncept »problemskega« izobraževanja. Opozarja pa, da emancipatorno izobraževanje lahko uspeva le ob podpori širšega družbenega gibanja, ki daje alternativo neoliberalnemu modelu družbe. Čeprav je tudi res, da doslej še nobeno antiglobalizacijsko gibanje ni razvilo resne alternative neoliberalnemu modelu globalizacije in tudi ne alternative dominantnim izobraževalnim modelom in procesom. 


\section{LITERATURA}

Althusser, L. (1980). Ideologija in ideološki aparati države. V L. Althusser, E. Balibar, P. Macherey in M. Pêcheux, Ideologija in estetski učinek (str. 35-97). Ljubljana: CZ.

Baethge, M. (1996). Individualization as hope and disaster. V K. Hurellmann (ur.), The Social World of Adolescents (str. 27-41). Berlin, New York: W. de Gruyter.

Bauman, Z. (1998). Globalization: The Human Consequences. New York: Columbia University Press. Bauman, Z. (2001). The Individualized Society. Cambridge: Polity.

Beck, U. (1998). Was ist Globalisierung? Frankfurt/M: Suhrkamp.

Beck, U. (2016). The Metamorphosis of the World. Cambridge: Polity.

Beck, U. in Beck-Gernsheim, E. (2002). Individualization. Institutionalized Individualism and Its Social and Political Consequences. London: Sage.

Belanger, P. (2016). Self-construction and Social Transformation: Lifelong, Lifewide and Life-deep Learning. Pridobljeno s http://unesdoc.unesco.org/images/0024/002444/244440e.pdf.

Bourdieu, P. (1985). Sozialer Raum und »Klassen«. Frankfurt/M: Suhrkamp.

Castells, M. (1997). The Power of Identity. Oxford: Blackwell Publishers.

Côté, J. E. in Allahar, A. L. (1994). Generation on Hold: Coming of Age in the Late Twentieth Century. New York: New York Univ. Press.

Côté, J. (2000). Arrested Adulthood. The Challenging Nature of Maturity and Identity. New York: New York Univ. Press.

Côté J. in Levine, C. (2002). Identity Formation, Agency and Culture. A Social Psychological Synthesis. London: LEA Publ.

Côté, J. (2007). Youth and the provision of resources. V H. Helve in J. Bynner (ur.), Youth and Social Capital (str. 59-70). London: The Tufnell Press.

Freire, P. (2000). Pedagogy of the Oppressed. New York: The Continuum International Publishing Company.

Gilligan, C. (1982). In a Different Voice. Massachusetts: Harvard Univ. Press.

Hagestad, G. O. (1997). Trends and Dilemmas in Life-Course Research: An International Perspective. V W. R. Heinz (ur.), Theoretical Advances in Life Course Research (str. 21-49). Weinheim: Deutscher Studien Verlag.

Heinz, W. R. (1997). Status Passages, Social Risks and the Life Course: A Conceptual Framework. V W. R. Heinz (ur.), Theoretical Advances in Life Course Research (str. 9-20). Weinheim: Deutscher Studien Verlag.

Jarvis, P. (2007). Globalisation, Lifelong Learning and the Learning Society. Sociological perspectives. London, New York: Routledge.

Kohli, M. (1994). Institutionalisierung und Individualisierung der Erwerbsbiographie. V U. Beck in E. Beck-Gernsheim (ur.), Riskante Freiheiten (str. 219-244). Frankfurt/M: Suhrkamp.

Krašovec, P. (2016). Še enkrat o neoliberalizmu I: Ekonomija. Andragoška spoznanja, 22(1), 57-70.

Kurdija, S. in Malnar, B. (2017). Slovensko javno mnenje 2016/2: Evropska družboslovna raziskava [datoteka kodirne knjige]. Ljubljana: Univerza v Ljubljani, Arhiv družboslovnih podatkov [izdelava, distribucija].

Lasch, C. (1979). The Culture of Narcissism. American Life in an Age of Dimnishing Expectations. New York: W. W. Norton \& Co.

Lasch, C. (2012). Kultura narcisizma. Ameriško življenje v času zmanjšanih pričakovanj. Ljubljana: MK. Luhmann, N. (1994). Kopierte Existenz und Karriere. Zur Herstellung von Individualität. V U. Beck in E. Beck-Gernsheim (ur.), Riskante Freiheiten (str. 191-200). Frankfurt/M: Suhrkamp. 
Močnik, R. (2009). Spisi iz humanistike. Ljubljana: Založba /*cf.

Schwartz, S., Côté, J. in Arnett, J. (2005). Identity and agency in emerging adulthood: Two Developmental Routes in the Individualization Process. Youth \& Society, 37(2), 201-229.

Sennett, R. (1999). The Corrosion of Character. The Personal Consequences of Work in the New Capitalism. New York, London: W. W. Norton \& Co.

Torres, C. A. (2009). Education and Neoliberal Globalization. New York: Routledge.

Ule, M. (2000). Sodobne identitete v vrtincu diskurzov. Ljubljana: Znanstveno in publicistično središče.

Ule, M. (2008). Za vedno mladi? Socialna psihologija odraščanja. Ljubljana: Založba FDV.

Ule, M. in Kuhar, M. (2003). Mladi, družina, starševstvo. Spremembe življenjskih potekov v pozni moderni. Ljubljana: Založba FDV.

Virno, P. (2003). Slovnica mnoštva. K analizi oblik sodobnega življenja. Ljubljana: Krt. 